\title{
Multielement Characterization and Antioxidant Activity of Italian Extra-Virgin Olive Oils
}

\author{
Maria Luisa Astolfi ${ }^{1}{ }^{*}$, Federico Marini ${ }^{1}$, Maria Agostina Frezzini ${ }^{2}$, Lorenzo Massimi ${ }^{2}$, \\ Anna Laura Capriotti ${ }^{1}$, Carmela Maria Montone ${ }^{1}$ and Silvia Canepari ${ }^{2}$ \\ ${ }^{1}$ Department of Chemistry, Sapienza University of Rome, Rome, Italy, ${ }^{2}$ Department of Environmental Biology, Sapienza University \\ of Rome, Rome, Italy
}

Food product safety and quality are closely related to the elemental composition of food. This study combined multielement analysis and chemometric tools to characterize 237 extra-virgin olive oil (EVOO) samples from 15 regions of Italy, and to verify the possibility of discriminating them according to different quality factors, such as varietal or geographical origin or whether they were organically or traditionally produced. Some elements have antioxidant properties, while others are toxic to humans or can promote oxidative degradation of EVOO samples. In particular, the antioxidant activity of oils' hydrophilic fraction was estimated and the concentrations of 45 elements were determined

OPEN ACCESS

Edited by:

Paolo Oliveri,

University of Genoa, Italy

Reviewed by: Itziar Ruisánchez,

University of Rovira i Virgili, Spain Alegria Carrasco-Pancorbo, University of Granada, Spain

*Correspondence: Maria Luisa Astolf marialuisa.astolfi@uniroma1.it

Specialty section:

This article was submitted to Analytical Chemistry, a section of the journal Frontiers in Chemistry

Received: 02 September 2021 Accepted: 19 October 2021 Published: 16 November 2021

Citation:

Astolfi ML, Marini F, Frezzini MA, Massimi L, Capriotti AL, Montone CM and Canepari S (2021) Multielement

Characterization and Antioxidant Activity of Italian Extra-Virgin Olive Oils.

Front. Chem. 9:769620.

doi: 10.3389/fchem.2021.769620 by inductively coupled plasma mass spectrometry (ICP-MS). At first, univariate and multivariate analyses of variance were used to compare the element concentrations, and statistically significant differences were found among samples from different regions. Successively, discriminant classification approaches were used to build a model for EVOO authentication, considering, in turn, various possible categorizations. The results have indicated that chemometric methods coupled with ICP-MS have the potential to discriminate and characterize the different types of EVOO, and to provide "typical" elemental fingerprints of the various categories of samples.

Keywords: authenticity, chemometrics, inductively coupled plasma mass spectrometry, olive oil, statistical analysis, trace elements, traceability

\section{INTRODUCTION}

The elemental composition of foods is of toxicological and nutritional interest and can be considered an important quality parameter (Astolfi et al., 2021a; 2020a; 2020b). In particular, the concentrations of trace elements in extra-virgin olive oil (EVOO) are also one of the criteria for the assessment of the quality regarding storable period and freshness (Choe and Min, 2006). In fact, some elements, such as $\mathrm{Ca}, \mathrm{Co}, \mathrm{Cu}, \mathrm{Fe}, \mathrm{Mg}, \mathrm{Mn}, \mathrm{Ni}$, and $\mathrm{Sn}$, can promote the oxidative degradation of this important component of the Mediterranean diet appreciated among consumers for its nutritional properties and specific flavor (Choe and $\mathrm{Min}, 2006$ ). Other elements (such as $\mathrm{As}, \mathrm{Cd}, \mathrm{Cr}, \mathrm{Cu}, \mathrm{Hg}$, and $\mathrm{Pb}$ ) present in EVOO are of great concern because they are toxic and potentially carcinogenic to humans even at low concentration (Tchounwou et al., 2012). The International Olive Council has established, as a quality criterion, a maximum residue level (MRL) for the content of $\mathrm{As}, \mathrm{Cu}, \mathrm{Pb}\left(0.1 \mathrm{mg} \mathrm{kg}^{-1}\right)$, and $\mathrm{Fe}\left(3 \mathrm{~m} \mathrm{~kg}^{-1}\right)$ in olive oils and olive-pomace oils (International Olive Council, 2019), and the maximum levels of $\mathrm{Cu}$ and $\mathrm{Fe}$ in other vegetable oils have been also legislated (Codex Stan 33-1981, 2021), varying from 0.1 up to $5.0 \mathrm{mg} \mathrm{kg}^{-1}$. Recently, element determination in EVOO samples has 
gained importance for oil geographical traceability and authentication (Cordella et al., 2002; Dugo et al., 2004; Benincasa et al., 2007; Cabrera Vique et al., 2012; Camin et al., 2010; Beltran et al., 2015; Bajoub et al., 2018; Aceto et al., 2019; Damak et al., 2019; Zaroual et al., 2021). In particular, elements are useful in the characterization of protected designations of origin (PDOs) or protected geographical indications (PGIs) (European Union (EU), 2012), and they can also contribute to determine EVOO geographical provenance of non-PDO oils (Beltran et al., 2015; Aceto et al., 2019). In fact, the presence of metals in EVOO varies according to their origin and can be due to natural contamination from the soil, environment, fertilizers, and genotype of the plant or to the production process and contact with storage materials (Zeiner et al., 2005; Chatzistathis et al., 2009; Kabata-Pendias, 2010; Lepri et al., 2011; Yaşar et al., 2012; Bakircioglu et al., 2013). A suitable statistical treatment of trace element data could allow a geographical characterization of different EVOO samples. Principal component analysis (PCA) and hierarchical cluster analysis (HCA) (Gumus et al., 2017; Luka and Akun, 2019; Russo et al., 2020; Savio et al., 2014), linear discriminant analysis (LDA) (Benincasa et al., 2007; CabreraVique et al., 2012; Beltran et al., 2015; Damak et al., 2019), classification trees (CTs) (Gumus et al., 2017), and artificial neural networks (ANNs) (Farmaki et al., 2012; GonzalezFernandez et al., 2019) have been used most.

Several beneficial implications of EVOO are derived from its antioxidant content (Dugo et al., 2020; Hannachi and Elfalleh, 2020). Intake of antioxidant compounds from oil, such as phenols, phenolic acids, and flavonoids (Capriotti et al., 2014), is usually related to health well-being. As well known, natural antioxidants play a key role in contrasting reactive species activity in living organisms, thus preventing oxidative stress-related diseases, such as cardiovascular and neurodegenerative illness and many other chronic disorders (Pérez-Jiménez et al., 2008; Cioffi et al., 2010; Šarolić et al., 2014). Moreover, antioxidants prevent lipid oxidations that cause quality degradation and unpleasant taste formation in edible oils (Christodouleas et al., 2015). Therefore, estimation of antioxidant capacity is crucial for evaluating oil's healthy and organoleptic properties. One of the most widely used in vitro procedures to routinely and globally estimate oil antioxidant power is the 2,2-diphenyl-1picrylhydrazyl spectrophotometric assay $(\mathrm{DPPH})$ that has the possibility of being easily applied to a high number of samples, allowing a great level of reliability (Kedare and Singh, 2011; Frezzini et al., 2019). The assay is based on the quantitative measurement of the decrease of absorbance due to the scavenging capacity of antioxidants present in the sample toward DPPH free radicals (Christodouleas et al., 2015).

All the described aspects making trace element determination, as well as the antioxidant activity of EVOO samples, are very important for both economic and health contexts (Zaroual et al., 2021; Bajoub et al., 2018). In particular, the European Union is the first producer, consumer, and exporter of olive oil in the world (Eurostat, 2019; IOC, 2018a,b). Italy follows Spain, the first world producer with an average of $20 \%$ of the total European olive oil production. About two-thirds of total Italian production is represented by EVOO (Carbone et al., 2018). Therefore, the use of a rapid and accurate analytical method for trace element analysis in EVOO has a great importance in quality control and food analysis (Llorent-Martínez et al., 2011; Shah and Soylak, 2021). Unfortunately, the determination of trace elements in EVOO samples is particularly difficult to perform, as some of them are present at very low concentrations and due to high complexity of the matrix (Shah and Soylak, 2021; Trindade et al., 2015). Sample preparation of EVOO samples is a critical step, and the determination of trace elements in EVOO requires very sensitive instrumental techniques such as inductively coupled plasma-mass spectrometry (ICP-MS) (Astolfi et al., 2021b).

The main purpose of this study is to evaluate the most significant relationships between element levels in EVOO and different categorizations, mostly related to the geographical origin using chemometric tools coupled with the ICP-MS method. For this purpose, 45 elements from a total of 237 EVOO samples from 15 Italian regions were analyzed. Also, the antioxidant activity of oils' hydrophilic fraction (HF) was estimated by the DPPH assay. The corresponding data set constituted the basis for building and validating classification models for the discrimination of the samples according to specific categorizations, which reflect possible quality attributes of the oils (and for which there could be a statistically significant number of individuals available). In particular, discriminant classification models were built using partial least square discriminant analysis (PLS-DA) to account for the possibility of dealing with correlated variables and low samples to variable ratios; moreover, to evaluate model stability and, at the same time, their reliability in an unbiased way, also in cases where the available number of samples per category was not too large, a repeated double cross-validation strategy (rDCV) was adopted.

\section{MATERIALS AND METHODS}

\section{Sample collection}

EVOO samples $(\mathrm{N}=237)$ were collected between 2017 and 2018 from 15 production regions of Italy and different cultivars. In particular, a total of 64 EVOO samples were with PDOs and 21 with PGIs (European Union (EU), 2012). Table 1 summarizes the number of EVOO samples according to their geographical provenances in terms of the regions. All samples $(\sim 100 \mathrm{mg})$ were kept in screw-capped glass vials in the dark at room temperature until analysis.

\section{Chemicals}

All the solutions were prepared with deionized water (18.3 $\mathrm{M} \Omega \mathrm{cm}$ resistivity) obtained from an Arioso (Human Corporation, Seoul, Korea) Power I RO-UP Scholar UV deionizer system. $\mathrm{HNO}_{3}$ at $67 \%$ (suprapure; Carlo Erba Reagents, Milan, Italy), $\mathrm{H}_{2} \mathrm{O}_{2}$ at $30 \%$ (suprapure; Merck KgaA, Darmstadt, Germany), and $\mathrm{Ar}, \mathrm{He}$, and $\mathrm{H}_{2}$ gases at $99.9995 \%$ (SOL Spa, Monza, Italy) were used.

For ICP-MS analysis, all calibration standard solutions were prepared from a 1,000-mg $\mathrm{l}^{-1}$ multielement standard solution (VWR International, Milan, Italy) by dilution with $10 \%(\mathrm{v} / \mathrm{v})$ $\mathrm{HNO}_{3}$ and $\mathrm{H}_{2} \mathrm{O}_{2}(2: 1 \mathrm{v} / \mathrm{v})$. Single standard solutions of In, Rh, Sc, 
TABLE 1 | Number of samples of extra virgin olive oil for each considered category.

\begin{tabular}{|c|c|c|c|c|c|c|}
\hline & \multirow[t]{2}{*}{ Region } & \multirow{2}{*}{$\begin{array}{l}\text { All } \\
\text { samples }\end{array}$} & \multicolumn{3}{|c|}{ Oil production } & \multirow{2}{*}{$\begin{array}{l}\text { Cultivar } \\
\text { (number of samples) }\end{array}$} \\
\hline & & & Organically & $\begin{array}{l}\text { Non- } \\
\text { organically }\end{array}$ & $\begin{array}{l}\text { Not } \\
\text { reported }\end{array}$ & \\
\hline \multirow[t]{5}{*}{$\begin{array}{l}\text { Northern } \\
\text { Italy }\end{array}$} & $\begin{array}{l}\text { Trentino Alto } \\
\text { Adige }\end{array}$ & 7 & 2 & 4 & 1 & Blend (3); Casaliva (1); Coratina (2) \\
\hline & Liguria & 6 & 0 & 4 & 2 & Lavagnina (1); Taggiasca (4) \\
\hline & Lombardy & 3 & 0 & 2 & 1 & Blend (1); Casaliva (1); Leccino (1) \\
\hline & Veneto & 3 & 1 & 2 & 0 & Blend (2); Grignano (1) \\
\hline & $\begin{array}{l}\text { Emilia } \\
\text { Romagna }\end{array}$ & 1 & 0 & 1 & 0 & Careggiolo (1) \\
\hline \multirow[t]{5}{*}{ Central Italy } & Abruzzo & 14 & 3 & 11 & 0 & Blend (8); Dritta (3); Intosso (3) \\
\hline & Lazio & 24 & 6 & 8 & 10 & Blend (5); Canino (3); Frantoio (1); Itrana (2); Leccino (2); Rosciola (1) \\
\hline & Marche & 7 & 2 & 5 & 0 & Ascolana (2); Blend (1); Leccino (1); Orbetana (1); Raggiola (2) \\
\hline & Toscany & 79 & 33 & 42 & 4 & $\begin{array}{l}\text { Blend (38); Arancino (1); Coratina (1); Frantoio (10); Leccino (4); Moraiolo (7); } \\
\text { Nocellara (1); Olivastra Seggianese (1); Pendolino (1); Raggiolo (1) }\end{array}$ \\
\hline & Umbria & 8 & 0 & 8 & 0 & Blend (8) \\
\hline \multirow[t]{5}{*}{$\begin{array}{l}\text { Southern } \\
\text { Italy }\end{array}$} & Apulia & 33 & 6 & 18 & 9 & $\begin{array}{l}\text { Blend (3); Coratina (18); Frantoio (1); Leccino (1); Ogliarola (2); Olivastra (1); } \\
\text { Peranzana (4); Pichioline (2) }\end{array}$ \\
\hline & Calabria & 12 & 5 & 6 & 1 & Blend (3); Carolea (2); Nocellara (1); Ottobratica (4) \\
\hline & Campania & 7 & 0 & 7 & 0 & Blend (2); Cammarotana (1); Ortice (1); Ravece (1); Salella (1) \\
\hline & Sardinia & 12 & 1 & 11 & 0 & Bosana (3); Blend (6); Semidana (1) \\
\hline & Sicily & 21 & 4 & 14 & 3 & $\begin{array}{l}\text { Blend (4); Biancolilla (2); Cerasuola (1); Leccio del Corno (1); Nocellara (9); } \\
\text { Tonda Iblea (3) }\end{array}$ \\
\hline
\end{tabular}

and Th (at $0.010 \mathrm{mg} \mathrm{l}^{-1}$ from $1,000 \pm 5 \mathrm{mg} \mathrm{l}^{-1}$; Merck KGaA, Darmstadt, Germany) and Y (at 0.005 from $1,000 \pm 2 \mathrm{mg} \mathrm{l}^{-1}$; Panreac Química, Barcelona, Spain) were used as internal standards. A multielemental solution containing $\mathrm{Ba}, \mathrm{Be}, \mathrm{Ce}$, $\mathrm{Co}$, In, Pb, Mg, Tl, and Th (at $0.005 \mathrm{mg} \mathrm{l}^{-1}$ from $10.00 \pm$ $0.05 \mathrm{mg} \mathrm{l}^{-1}$; Spectro Pure, Ricca Chemical Company, Arlington, TX, USA) was used to check the instrument performance.

For the estimation of the antioxidant activity of EVOO samples, DPPH was purchased from Sigma Aldrich Co. (St. Louis, MO, USA).

\section{Sample preparation and analysis}

\subsubsection{Analysis of elements}

Duplicate samples $(\sim 0.5 \mathrm{~g})$ of each EVOO variety were accurately weighed in 10-ml disposable graduated tubes (Artiglass, Due Carrare, PD, Italy). Then, $5 \mathrm{ml}$ reagent mixture of $10 \%(\mathrm{v} / \mathrm{v})$ $\mathrm{HNO}_{3}$ and $\mathrm{H}_{2} \mathrm{O}_{2}(2: 1 \mathrm{v} / \mathrm{v})$ was added to each tube and heated in a water bath (WB12, Argo Lab, Modena, Italy) at $95^{\circ} \mathrm{C}$ for $40 \mathrm{~min}$ (Astolfi et al., 2021b). The lower aqueous phase was transferred into a clean tube and subjected to the ICP-MS (820-MS; Bruker, Bremen, Germany) analysis without further dilutions. The elements were monitored in standard and collision-reaction interface (CRI) modes to check and reduce possible polyatomic interference, and the following isotopes were used: ${ }^{7} \mathrm{Li},{ }^{9} \mathrm{Be},{ }^{11} \mathrm{~B},{ }^{23} \mathrm{Na},{ }^{24} \mathrm{Mg},{ }^{27} \mathrm{Al},{ }^{28} \mathrm{Si},{ }^{31} \mathrm{P},{ }^{39} \mathrm{~K},{ }^{44} \mathrm{Ca},{ }^{49} \mathrm{Ti},{ }^{51} \mathrm{~V},{ }^{52} \mathrm{Cr}$, ${ }^{55} \mathrm{Mn},{ }^{57} \mathrm{Fe},{ }^{59} \mathrm{Co},{ }^{60} \mathrm{Ni},{ }^{65} \mathrm{Cu},{ }^{66} \mathrm{Zn},{ }^{71} \mathrm{Ga},{ }^{75} \mathrm{As},{ }^{78} \mathrm{Se},{ }^{85} \mathrm{Rb},{ }^{88} \mathrm{Sr}$, ${ }^{90} \mathrm{Zr},{ }^{93} \mathrm{Nb},{ }^{98} \mathrm{Mo},{ }^{107} \mathrm{Ag},{ }^{112} \mathrm{Cd},{ }^{118} \mathrm{Sn},{ }^{121} \mathrm{Sb},{ }^{125} \mathrm{Te},{ }^{133} \mathrm{Cs},{ }^{137} \mathrm{Ba}$, ${ }^{139} \mathrm{La},{ }^{140} \mathrm{Ce},{ }^{141} \mathrm{Pr},{ }^{146} \mathrm{Nd},{ }^{159} \mathrm{~Tb},{ }^{163} \mathrm{Dy},{ }^{182} \mathrm{~W},{ }^{205} \mathrm{Tl},{ }^{208} \mathrm{~Pb},{ }^{209} \mathrm{Bi}$, and ${ }^{238} \mathrm{U}$. CRI was used with $\mathrm{He}\left(30 \mathrm{ml} \mathrm{min}{ }^{-1}\right)$ and $\mathrm{H}_{2}(70 \mathrm{ml}$ $\mathrm{min}^{-1}$ ) as cell gases. The ICP-MS operating conditions and parameters were as follows: radiofrequency power $1,400 \mathrm{~W}$; plasma Ar flow rate $181 \mathrm{~min}^{-1}$; auxiliary Ar flow rate 1.81 $\min ^{-1}$; nebulizer gas flow rate $0.91 \mathrm{~min}^{-1}$; peak hopping scanning mode; steady-state analysis mode; dwell time between 50 and $100 \mathrm{~ms}$, pump rate $3 \mathrm{rpm}$; five scans/replicate; and three replicates/sample. For the quantitative analysis of EVOO samples, calibration curves were built on seven different concentrations between 0.00025 and $0.05 \mathrm{mg} \mathrm{l}^{-1}$ and 0.0125 and $5 \mathrm{mg} \mathrm{l}^{-1}$ for all trace and major elements, respectively.

\subsubsection{Estimation of antioxidant activity}

DPPH assay was performed according to the procedure described by Šarolić et al. (2014) with slight modifications. In detail, $\sim 0.5 \mathrm{~g}$ of each EVOO sample was mixed with $1 \mathrm{ml}$ of 80:20 (v/v) $\mathrm{CH}_{3} \mathrm{OH}: \mathrm{H}_{2} \mathrm{O}$, and the mixture was blended in an ultrasonic bath (PROCLEAN 10.0 ultrasonic cleaner; Ulsonix, Berlin, Germany) for $15 \mathrm{~min}$ at $30^{\circ} \mathrm{C}$. When the two phases appeared, the hydrophilic phase was collected, and the extraction was repeated another two times. Then, the hydrophilic extracts were combined to get a homogeneous sample. To perform DPPH assay, $50 \mu \mathrm{l}$ of the HF sample was added to $2 \mathrm{ml}$ of methanolic DPPH $(0.04 \mathrm{mM})$, then the mixture was shaken for $30 \mathrm{~min}$ by rotating agitation (60 rpm; rotator; Glas-Col, Terre Haute, IN, USA) at room temperature in the dark and analyzed by UV-Vis spectrophotometry (Varian Cary 50 Bio UV-Vis; Varian Inc., Palo Alto, CA, USA) set at $517 \mathrm{~nm}$, by measuring the sample absorbance decrease against the control (blank solution). Solutions were prepared daily and used fresh, and three replicates of each type of oil were performed. The DPPH radical scavenging activity was calculated in terms of percentage reduction of DPPH according to the following equation: 


$$
\mathrm{DPPH}[\%]=\frac{\left(\mathrm{A}_{0}-\mathrm{A}_{\mathrm{S}}\right)}{\mathrm{A}_{0}} \times 100
$$

where $A_{0}$ represents the absorbance of the blank solution and $A_{S}$ is the absorbance of the sample.

\section{Quality assurance}

The method accuracy for element determination was checked by recovery assays in the EVOO samples adding element at the low (0.005 and $\left.0.02 \mathrm{mg} \mathrm{l}^{-1}\right)$ and high $\left(0.2\right.$ and $\left.1 \mathrm{mg} \mathrm{l}^{-1}\right)$ spike concentrations for all trace and major elements $(\mathrm{B}, \mathrm{Ca}, \mathrm{K}, \mathrm{Mg}$, $\mathrm{Na}, \mathrm{P}, \mathrm{Si}$, and $\mathrm{Sr}$ ) and always in the linear calibration range. In addition, accuracy was tested by a certified reference material (Conostan S-21; lot number: 21550100) obtained from SCP SCIENCE (Baie D'Urfé, Canada). The recoveries fell within $20 \%$ of the expected value and reproducibility lower than $20 \%$ (Astolfi et al., 2021b). The method detection and quantification limits (MDL and MQL, respectively) were in the range 0.004-510 and 2.5-5,000 $\mathrm{g} \mathrm{kg}^{-1}$, respectively. Only the $\mathrm{Ca}, \mathrm{Cr}, \mathrm{Mg}, \mathrm{Mn}, \mathrm{Ni}$, $\mathrm{P}, \mathrm{Rb}, \mathrm{Ti}$, and $\mathrm{Zn}$ levels in the EVOO samples were $100 \%$ greater than the MDL. The possible instrumental drift for the ICP-MS analysis was checked and corrected using an internal standard solution of In, Rh, Sc, Th, and Y (Astolfi et al., 2021b; 2020c). Blank samples and control standards were tested every 20 samples in each run, and recalibration was performed every 100 samples.

\section{Statistical analysis}

The data were statistically evaluated according to the procedures of the software SPSS Statistics 25 (IBM Corp., Armonk, NY, USA) for univariate analysis. Analytical replicates were averaged prior to the successive elaboration. Non-parametric tests (Kruskal-Wallis and pairwise post-hoc) were applied because of the unequal numbers of samples per group and the not normal distribution (Soliani, 2003). The element concentrations measured below MDL were substituted by its half value $(\mathrm{MDL} / 2)$ for the statistical elaboration (Farmaki et al., 2012). A $p$-value lower than 0.05 was considered statistically significant.

Partial least square discriminant analysis (PLS-DA; Ståhle and Wold, 1987; Barker and Rayens, 2003) implemented through inhouse written functions running under the Matlab environment (R2015b, v.8.6, The MathWorks Inc., Natick, MA, USA) was used to build multivariate classification models. PLS-DA is a regression-based classification model which operates by coding class belonging by means of a dummy binary response matrix (or vector, when the problems involve only pairs of classes, as in the present study). In particular, if discrimination is sought between two categories, class belonging of the training samples is described by the vector $y$, having 1 in correspondence of all the individuals from the first class and 0 in all the remaining positions (i.e., those corresponding to the second group). A PLS model (Wold et al., 1983) is then built between the experimental data $\mathrm{X}$ and the dummy vector $\mathrm{y}$, and the predicted value of the response $(\hat{y})$ constitutes the basis for the classification of the samples: since the predicted responses are real-valued, an optimal threshold $y_{\text {thres }}$ has to be calculated so that, if the predicted
TABLE 2 | Method detection limits (MDL; $\mu \mathrm{g} \mathrm{kg}^{-1}$ ) and element levels [median, minimum (min) and maximum (max); $\mu \mathrm{g} \mathrm{kg}^{-1}$ ] in extra-virgin olive oils (EVOO; $n=237$ ) from all over Italy.

\begin{tabular}{|c|c|c|c|c|c|}
\hline \multirow[t]{2}{*}{ Element } & \multirow[t]{2}{*}{ MDL } & \multicolumn{4}{|c|}{ Italian EVOO samples } \\
\hline & & $\% \mathbf{N}>$ MDL & Median & Min & Max \\
\hline $\mathrm{Ag}$ & 0.06 & 27 & $<0.06$ & $<0.06$ & 0.86 \\
\hline $\mathrm{Al}$ & 9 & 85 & 34 & $<9$ & 1,300 \\
\hline As & 0.3 & 28 & $<0.3$ & $<0.3$ & 4.0 \\
\hline$B$ & 20 & 16 & $<20$ & $<20$ & 770 \\
\hline $\mathrm{Ba}$ & 0.7 & 49 & $<0.7$ & $<0.7$ & 175 \\
\hline $\mathrm{Be}$ & 0.004 & 43 & $<0.004$ & $<0.004$ & 0.431 \\
\hline $\mathrm{Bi}$ & 0.1 & 23 & $<0.1$ & $<0.1$ & 1.0 \\
\hline $\mathrm{Ca}$ & 510 & 100 & 4,090 & 1,230 & 35,700 \\
\hline $\mathrm{Cd}$ & 0.07 & 67 & 0.09 & $<0.07$ & 0.97 \\
\hline $\mathrm{Ce}$ & 0.1 & 65 & 0.2 & 0.1 & 3.5 \\
\hline Co & 0.05 & 70 & 0.12 & $<0.05$ & 2.16 \\
\hline $\mathrm{Cr}$ & 0.3 & 100 & 5 & 0.4 & 839 \\
\hline Cs & 0.007 & 55 & 0.008 & $<0.007$ & 0.101 \\
\hline $\mathrm{Cu}$ & 0.6 & 99 & 3.2 & $<0.6$ & 41.6 \\
\hline Dy & 0.005 & 19 & $<0.005$ & $<0.005$ & 0.055 \\
\hline $\mathrm{Fe}$ & 12 & 99 & 77 & $<12$ & 582 \\
\hline $\mathrm{Ga}$ & 0.06 & 15 & $<0.06$ & $<0.06$ & 0.69 \\
\hline K & 40 & 24 & $<40$ & $<40$ & 939 \\
\hline $\mathrm{La}$ & 0.05 & 70 & 0.10 & $<0.05$ & 0.79 \\
\hline $\mathrm{Li}$ & 0.06 & 32 & $<0.06$ & $<0.06$ & 6.07 \\
\hline $\mathrm{Mg}$ & 10 & 100 & 91 & 21 & 723 \\
\hline $\mathrm{Mn}$ & 0.5 & 100 & 2.4 & 1.1 & 43.5 \\
\hline Mo & 0.3 & 20 & $<0.3$ & $<0.3$ & 2.0 \\
\hline $\mathrm{Na}$ & 25 & 98 & 110 & $<25$ & 585 \\
\hline $\mathrm{Nb}$ & 0.04 & 7 & $<0.04$ & $<0.04$ & 0.11 \\
\hline $\mathrm{Nd}$ & 0.03 & 52 & 0.03 & $<0.03$ & 13.8 \\
\hline $\mathrm{Ni}$ & 0.5 & 100 & 5.6 & 2.1 & 49.7 \\
\hline$P$ & 60 & 100 & 272 & 127 & 650 \\
\hline $\mathrm{Pb}$ & 0.3 & 99 & 0.9 & $<0.3$ & 22.1 \\
\hline $\operatorname{Pr}$ & 0.008 & 40 & $<0.008$ & $<0.008$ & 1.65 \\
\hline $\mathrm{Rb}$ & 0.06 & 99 & 0.24 & $<0.06$ & 1.77 \\
\hline $\mathrm{Sb}$ & 0.02 & 16 & $<0.02$ & $<0.02$ & 0.37 \\
\hline $\mathrm{Se}$ & 0.6 & 48 & $<0.6$ & $<0.6$ & 7.8 \\
\hline $\mathrm{Si}$ & 270 & 1 & $<270$ & $<270$ & 3,340 \\
\hline Sn & 0.06 & 63 & 0.08 & $<0.06$ & 1.94 \\
\hline $\mathrm{Sr}$ & 1 & 65 & 3 & 1 & 58 \\
\hline $\mathrm{Tb}$ & 0.006 & 19 & $<0.006$ & $<0.006$ & 1.28 \\
\hline $\mathrm{Te}$ & 0.03 & 3 & $<0.03$ & $<0.03$ & 0.06 \\
\hline $\mathrm{Ti}$ & 0.4 & 100 & 1.9 & 0.8 & 10.7 \\
\hline $\mathrm{Tl}$ & 0.06 & 0 & $<0.06$ & $<0.06$ & $<0.06$ \\
\hline$U$ & 0.005 & 30 & $<0.005$ & $<0.005$ & 0.050 \\
\hline V & 0.08 & 98 & 0.53 & $<0.08$ & 1.40 \\
\hline W & 0.3 & 38 & $<0.3$ & $<0.3$ & 5.1 \\
\hline $\mathrm{Zn}$ & 20 & 100 & 111 & 54 & 749 \\
\hline $\mathrm{Zr}$ & 0.1 & 57 & $<0.1$ & $<0.1$ & 2.3 \\
\hline
\end{tabular}

response is greater than $y_{\text {thres }}$, the sample is predicted as class 1 , otherwise as class 2 . In the present study, the threshold was calculated by applying LDA on the predicted responses calculated on the training samples (Perez et al., 2009).

The reliability of the classification models was evaluated by means of a repeated double-cross-validation ( $\mathrm{rDCV}$ ) procedure (Filzmoser et al., 2009). Double cross-validation (DCV) is a validation strategy which involves two nested loops of crossvalidation: an inner loop for model selection (i.e., for choosing the optimal number of latent variables) and an outer loop which mimics an external (i.e., not involved in any model building and/ 
or optimization stage) test set, to be used for estimating the prediction and generalization ability. In order to avoid that the performances of the model depend on a particular sample splitting scheme, the procedure is repeated a sufficient number of times, changing the distribution of the individuals across the different cancelation groups, hence the name "repeated" DCV. Repeating the double-cross-validation procedure allows also having multiple predictions for the same samples, which translates to the possibility of estimating confidence intervals for all the classification figures of merit and model parameters.

\section{RESULTS AND DISCUSSION}

\section{Levels of elements}

Table 2 shows the concentration of the elements in EVOO from all over Italy. The content of $\mathrm{Tl}$ was below the respective MDL $\left(0.06 \mu \mathrm{gg}^{-1}\right)$ in all the samples. $\mathrm{Si}, \mathrm{Te}$, and $\mathrm{Nb}$ were found above the MDL $\left(270,0.03\right.$, and $0.04 \mu \mathrm{g} \mathrm{kg}^{-1}$, respectively) only in $1 \%$, $3 \%$, and $7 \%$ of all samples. Only the $\mathrm{Ca}, \mathrm{Cr}, \mathrm{Mg}, \mathrm{Mn}, \mathrm{Ni}, \mathrm{P}, \mathrm{Ti}$, and $\mathrm{Zn}$ levels in the EVOO samples were $100 \%$ greater than the MDL. The maximum concentrations for As $\left(4.0 \mu \mathrm{g} \mathrm{kg}^{-1}\right), \mathrm{Cu}(41.6 \mu \mathrm{g}$ $\left.\mathrm{kg}^{-1}\right), \mathrm{Fe}\left(582 \mu \mathrm{g} \mathrm{kg}^{-1}\right)$, and $\mathrm{Pb}\left(22.1 \mu \mathrm{g} \mathrm{kg}^{-1}\right)$ were lower than the MRLs established by the IOC for olive and pomace-olive oils, which are $100 \mu \mathrm{g} \mathrm{kg}^{-1}$ for $\mathrm{As}, \mathrm{Cu}$, and $\mathrm{Pb}$ and 3,000 $\mu \mathrm{g} \mathrm{kg}^{-1}$ for $\mathrm{Fe}$ (International Olive Council, 2009). Calcium showed the highest concentration ranging from 1,230 to $35,700 \mu \mathrm{g} \mathrm{kg}$, whereas from 10 - to 50 -fold lower levels were found for $\mathrm{Fe}, \mathrm{Mg}, \mathrm{Na}, \mathrm{P}$, and $\mathrm{Zn}$ (median $=77,91,110,272$, and $111 \mu \mathrm{g} \mathrm{kg}^{-1}$, respectively).

Concentrations of elements obtained in this study were compared to levels measured in EVOO from several other Mediterranean countries (Supplementary Tables S1-S4). Levels of many elements showed wide variability even within the same country. The Ag, Ba, P, and Sn data were not considered because these elements are not completely extracted with the method used. As regards the content of B, Be, Dy, Nd, Pr, Si, Tb, and $\mathrm{Te}$, we could not find other data for EVOO in the literature. Our results were similar to those reported by another study on Italian EVOO (Benincasa et al., 2007); on the contrary, they differed significantly from other data concerning most of the elements investigated in the EVOOs of Spain (Beltran et al., 2015; Llorent-Martínez et al., 2014), Croatia (Pošćić et al., 2019), Tunisia (Damak et al., 2019), and Turkey (Gumus et al., 2017). The concentrations of $\mathrm{Ca}\left(1,230-35,700 \mu \mathrm{g} \mathrm{kg}^{-1}\right), \mathrm{Cr}$ $\left(0.4-839 \mu \mathrm{g} \mathrm{kg}^{-1}\right), \mathrm{Mg}\left(21-723 \mu \mathrm{g} \mathrm{kg}{ }^{-1}\right)$, and $\mathrm{Ni}(2.1-49.7 \mu \mathrm{g}$ $\mathrm{kg}^{-1}$ ) found in this study were in the same range to that found in other Italian EVOO $\left(\mathrm{Ca}=1850-26,900 \mu \mathrm{g} \mathrm{kg}^{-1} ; \mathrm{Cr}=116-437 \mu \mathrm{g}\right.$ $\mathrm{kg}^{-1} ; \mathrm{Mg}=56-1,030 \mu \mathrm{g} \mathrm{kg}^{-1}$; and $\mathrm{Ni}=$ nd-46.9 $\left.\mu \mathrm{g} \mathrm{kg}^{-1}\right)$ as reported by Benincasa et al. (2007), but from 10 to 100 times higher than the levels reported in Croatian (Pošćić et al., 2019) and Turkish EVOO (Gumus et al., 2017). Fe concentrations $\left(<12-582 \mu \mathrm{g} \mathrm{kg}^{-1}\right)$ varied from 100 times lower to 100 times higher than the level of Fe quantified in EVOO from Turkey $\left(1-14,670 \mu \mathrm{g} \mathrm{kg}^{-1}\right)$ by Gumus et al. (2017) and Croatia $\left(0.19-2.57 \mu \mathrm{g} \mathrm{kg}^{-1}\right)$ by Pošćić et al. (2019) or Spain (0.5-1.2 $\mu \mathrm{g}$ $\mathrm{kg}^{-1}$ ) by Beltran et al. (2015), respectively. This variability in the concentrations of the elements present in EVOO samples may depend on various factors related to the geochemistry of the provenance soil but also to physiological aspects typical of the species from which a particular EVOO derives (Giaccio and Vicentini, 2008).

Grouping the data according to geographic origin as north (Emilia Romagna, Liguria, Lombardy, Trentino Alto Adige, and Veneto), center (Abruzzo, Lazio, Marche, Tuscany and Umbria), and south (Apulia, Calabria, Campania, Sardinia and Sicily) of Italy, it is possible to identify elements that differ significantly from one group to another (Table 3). In particular, the EVOO samples from northern Italy had significantly higher levels of Cs, $\mathrm{Fe}, \mathrm{Na}, \mathrm{P}$, and $\mathrm{Pr}$ than those from central Italy and Fe, Pr, and $\mathrm{U}$ than those from southern Italy. Both Fe and Pr appear to provide a good tool for tracing the EVOO production chain in accord with other authors (Aceto et al., 2019; Damak et al., 2019). Iron is common in silicates and carbonates present in soil (Pohl, 2011); however, some authors reported that Fe may be present in edible oils as a result of storage and processing contaminations (Mendil et al., 2009; Zeiner et al., 2010). Praseodymium and the other lanthanides do not have a defined role in the metabolism of plants; therefore, their distribution remains almost unchanged in the passage from the soil to the fruits (Aceto et al., 2019). For this reason, these elements can be used as fingerprints to discriminate the geographic origin of the EVOO samples (Farmaki et al., 2012; Aceto et al., 2019). In addition, the analysis of some elements in EVOO, such as Cs and Rb, which can be easily mobilized in the soil, can be linked to a geogenic source rather than an anthropogenic origin (such as extraction process or cultivation practices) and can help in the geographical traceability of EVOO samples (Kelly, Heaton, \& Hoogewerff, 2005).

By comparing the concentrations of the elements in the EVOO samples from each region (Supplementary Tables S5-S7), the number of elements that differ significantly increases. Table 4 shows a summary of all the elements that differ significantly according to the region. Emilia Romagna was not considered for the comparison because there was only one EVOO sample to consider. EVOOs from Lombardy did not have levels of elements that are significantly different from those of oils from all other regions. Considering the other oils of northern Italy, the EVOOs from Trentino and Liguria differed significantly from the EVOOs from Marche only for the content of $\mathrm{Na}$, which in the EVOOs from Marche (median $=38 \mu \mathrm{g} \mathrm{kg}^{-1}$ ) was about four times lower, while the EVOOs from Veneto had a higher content of $\mathrm{Fe}$ $\left(\right.$ median $\left.=218 \mu \mathrm{g} \mathrm{kg}^{-1}\right)$ than the oils from Abruzzo (median = $15 \mu \mathrm{g} \mathrm{kg}^{-1}$ ) and a higher content of $\mathrm{Fe}$ and $\mathrm{Na}$ (median $=218$ and $174 \mu \mathrm{g} \mathrm{kg}^{-1}$, respectively) compared to the Marche. The EVOO samples from Lazio differed significantly for a large number of elements (Ba, Ca, Cd, Ce, Cs, Dy, Ga, La, Mg, Na, Nd, Pr, Pb, Rb, $\mathrm{Sb}, \mathrm{Sr}, \mathrm{Tb}, \mathrm{Ti}, \mathrm{U})$ compared to Tuscany, Abruzzo, Campania, and Marche. In all cases, levels of Cd (median $\left.=0.14 \mu \mathrm{g} \mathrm{kg}^{-1}\right)$, La $\left(\right.$ median $=0.20 \mu \mathrm{g} \mathrm{kg}^{-1}$ ), and $\mathrm{Rb}\left(\right.$ median $=0.48 \mu \mathrm{g} \mathrm{kg}^{-1}$ ) were higher than those of oils from other regions mentioned above.

\section{Antioxidant activity}

Following the extraction and storage of EVOO, it is inevitable that an oxidation process occurs, which leads to a deterioration of the oil (Bendini et al., 2007). Some factors such as temperature, light, 
TABLE 3 | Element levels [median, minimum (min) and maximum (max); $\mu \mathrm{g} \mathrm{kg}^{-1}$ ] in extra-virgin olive oils from north $(\mathrm{n}=20)$, central $(n=132)$ and south $(n=85)$ Italy.

\begin{tabular}{|c|c|c|c|c|c|c|c|c|c|c|c|c|}
\hline \multirow[t]{2}{*}{ Element } & \multicolumn{4}{|c|}{ North Italy ${ }^{a}$} & \multicolumn{4}{|c|}{ Central Italy ${ }^{b}$} & \multicolumn{4}{|c|}{ South Italyc } \\
\hline & $\% \mathbf{N}>$ MDL & Median & Min & Max & $\% \mathbf{N}>$ MDL & Median & Min & Max & $\% \mathbf{N}>$ MDL & Median & Min & Max \\
\hline $\mathrm{Ag}$ & 25 & $<0.06$ & $<0.06$ & 0.26 & 30 & $<0.06$ & $<0.06$ & 0.86 & 25 & $<0.06$ & $<0.06$ & 0.22 \\
\hline $\mathrm{Al}$ & 75 & 32 & $<9$ & 615 & 86 & 34 & $<9$ & 1,291 & 86 & 34 & $<9$ & 1,298 \\
\hline As & 25 & $<0.3$ & $<0.3$ & 2.8 & 28 & $<0.3$ & $<0.3$ & 4.0 & 28 & $<0.3$ & $<0.3$ & 2.2 \\
\hline$B$ & 20 & $<20$ & $<20$ & 85 & 15 & $<20$ & $<20$ & 734 & 16 & $<20$ & $<20$ & 770 \\
\hline $\mathrm{Ba}$ & 50 & 0.6 & 0.4 & 99.5 & 49 & 2.9 & $<0.7$ & 175 & 48 & $<0.7$ & $<0.7$ & 147 \\
\hline $\mathrm{Be}$ & 40 & $<0.004$ & $<0.004$ & 0.431 & 37 & $<0.004$ & $<0.004$ & 0.272 & 49 & 0.004 & $<0.004$ & 0.061 \\
\hline $\mathrm{Bi}$ & 40 & $<0.1$ & $<0.1$ & 0.2 & 23 & $<0.1$ & $<0.1$ & 0.4 & 19 & $<0.1$ & $<0.1$ & 1.0 \\
\hline $\mathrm{Ca}$ & 100 & 4,590 & 1,480 & 9,170 & 100 & 3,648 & 1,229 & 35,709 & 99 & 4,278 & 1,432 & 24,122 \\
\hline $\mathrm{Cd}$ & 70 & 0.12 & $<0.07$ & 0.33 & 66 & 0.09 & $<0.07$ & 0.97 & 67 & 0.09 & $<0.07$ & 0.61 \\
\hline $\mathrm{Ce}$ & 70 & 0.2 & $<0.1$ & 0.7 & 69 & 0.2 & 0.1 & 3.5 & 60 & 0.2 & 0.1 & 1.0 \\
\hline Co & 90 & 0.11 & $<0.05$ & 0.59 & 68 & 0.13 & $<0.05$ & 1.23 & 69 & 0.08 & $<0.05$ & 2.16 \\
\hline $\mathrm{Cr}$ & 100 & 3.7 & 0.5 & 839 & 99 & 5.0 & 0.4 & 123 & 100 & 4.1 & 0.5 & 533 \\
\hline Cs & 80 & $0.013^{a}$ & $<0.007$ & 0.080 & 52 & $0.007^{a}$ & $<0.007$ & 0.084 & 55 & 0.008 & $<0.007$ & 0.101 \\
\hline $\mathrm{Cu}$ & 100 & 4.6 & $<0.6$ & 20.7 & 99 & 3.0 & $<0.6$ & 40.9 & 100 & 3.3 & $<0.6$ & 41.6 \\
\hline Dy & 20 & $<0.005$ & $<0.005$ & 0.010 & 20 & $<0.005$ & $<0.005$ & 0.026 & 17 & $<0.005$ & $<0.005$ & 0.055 \\
\hline $\mathrm{Fe}$ & 100 & $158^{\mathrm{a}, \mathrm{b}}$ & $<12$ & 495 & 99 & $70^{a}$ & $<12$ & 403 & 100 & $86^{b}$ & 14 & 582 \\
\hline $\mathrm{Ga}$ & 35 & $<0.06$ & $<0.06$ & 0.33 & 11 & $<0.06$ & $<0.06$ & 0.69 & 16 & $<0.06$ & $<0.06$ & 0.59 \\
\hline $\mathrm{K}$ & 40 & $<40$ & $<40$ & 293 & 20 & $<40$ & $<40$ & 673 & 26 & $<40$ & $<40$ & 939 \\
\hline $\mathrm{La}$ & 80 & 0.13 & $<0.05$ & 0.41 & 70 & 0.08 & $<0.05$ & 0.79 & 67 & 0.11 & $<0.05$ & 0.71 \\
\hline $\mathrm{Li}$ & 40 & $<0.06$ & $<0.06$ & 1.67 & 29 & $<0.06$ & $<0.06$ & 6.07 & 35 & $<0.06$ & $<0.06$ & 4.42 \\
\hline $\mathrm{Mg}$ & 100 & 97 & 37 & 262 & 100 & 90 & 21 & 723 & 99 & 96 & 28 & 613 \\
\hline $\mathrm{Mn}$ & 100 & 2.7 & 1.5 & 7.1 & 99 & 2.3 & 1.1 & 18.6 & 100 & 2.6 & 1.4 & 43.5 \\
\hline Mo & 30 & $<0.3$ & $<0.3$ & 1.3 & 19 & $<0.3$ & $<0.3$ & 1.7 & 20 & $<0.3$ & $<0.3$ & 2.0 \\
\hline $\mathrm{Na}$ & 100 & $131^{a}$ & 87 & 331 & 99 & $102^{a}$ & $<25$ & 585 & 100 & 114 & $<25$ & 513 \\
\hline $\mathrm{Nb}$ & 15 & $<0.04$ & $<0.04$ & 0.05 & 5 & $<0.04$ & $<0.04$ & 0.06 & 8 & $<0.04$ & $<0.04$ & 0.11 \\
\hline $\mathrm{Nd}$ & 80 & 0.06 & $<0.03$ & 1.39 & 47 & $<0.03$ & $<0.03$ & 6.43 & 53 & 0.03 & $<0.03$ & 13.8 \\
\hline $\mathrm{Ni}$ & 100 & 5.2 & 2.5 & 29.5 & 100 & 6.0 & 2.1 & 40.6 & 100 & 5.4 & 2.4 & 49.7 \\
\hline $\mathrm{P}$ & 100 & $309^{a}$ & 220 & 650 & 99 & $269^{a}$ & 127 & 522 & 100 & 272 & 189 & 548 \\
\hline $\mathrm{Pb}$ & 100 & 1.2 & $<0.3$ & 4.3 & 100 & 0.8 & $<0.3$ & 22.1 & 100 & 1.1 & $<0.3$ & 8.7 \\
\hline $\operatorname{Pr}$ & 70 & $0.012^{a, b}$ & $<0.008$ & 0.359 & 38 & $<0.008^{\mathrm{a}}$ & $<0.008$ & 1.58 & 35 & $<0.008^{b}$ & $<0.008$ & 1.65 \\
\hline $\mathrm{Rb}$ & 95 & 0.29 & $<0.06$ & 1.10 & 100 & 0.24 & 0.06 & 1.77 & 100 & 0.26 & $<0.06$ & 1.36 \\
\hline $\mathrm{Sb}$ & 10 & $<0.02$ & $<0.02$ & 0.04 & 17 & $<0.02$ & $<0.02$ & 0.37 & 16 & $<0.02$ & $<0.02$ & 0.14 \\
\hline $\mathrm{Se}$ & 55 & 0.6 & $<0.6$ & 6.8 & 49 & $<0.6$ & $<0.6$ & 6.9 & 44 & 0.6 & $<0.6$ & 7.8 \\
\hline $\mathrm{Si}$ & 0 & $<270$ & $<270$ & $<270$ & 1 & $<270$ & $<270$ & 3,344 & 1 & $<270$ & $<270$ & 442 \\
\hline Sn & 80 & 0.10 & $<0.06$ & 0.45 & 59 & 0.06 & $<0.06$ & 0.60 & 65 & 0.09 & $<0.06$ & 1.94 \\
\hline $\mathrm{Sr}$ & 80 & 3 & 1 & 7 & 64 & 3 & 1 & 34 & 63 & 3 & 1 & 58 \\
\hline $\mathrm{Tb}$ & 25 & $<0.006$ & $<0.006$ & 0.112 & 20 & $<0.006$ & $<0.006$ & 1.13 & 16 & $<0.006$ & $<0.006$ & 1.28 \\
\hline $\mathrm{Te}$ & 5 & $<0.03$ & $<0.03$ & 0.05 & 1 & $<0.03$ & $<0.03$ & 0.05 & 6 & $<0.03$ & $<0.03$ & 0.06 \\
\hline $\mathrm{Ti}$ & 100 & 2.2 & 1.2 & 8.1 & 99 & 1.8 & 0.8 & 5.6 & 100 & 2.1 & 1.1 & 10.7 \\
\hline $\mathrm{TI}$ & 0 & $<0.06$ & $<0.06$ & $<0.06$ & 1 & $<0.06$ & $<0.06$ & 0.08 & 0 & $<0.06$ & $<0.06$ & 0.03 \\
\hline$U$ & 55 & $0.006^{a}$ & $<0.005$ & 0.044 & 31 & $<0.005$ & $<0.005$ & 0.044 & 24 & $<0.005^{\mathrm{a}}$ & $<0.005$ & 0.050 \\
\hline V & 100 & 0.50 & $<0.08$ & 1.04 & 99 & 0.52 & $<0.08$ & 1.21 & 100 & 0.55 & $<0.08$ & 1.40 \\
\hline W & 40 & $<0.3$ & $<0.3$ & 2.0 & 37 & $<0.3$ & $<0.3$ & 2.3 & 39 & $<0.3$ & $<0.3$ & 5.1 \\
\hline $\mathrm{Zn}$ & 100 & 145 & 55 & 283 & 99 & 98 & 54 & 749 & 99 & 143 & 57 & 672 \\
\hline $\mathrm{Zr}$ & 55 & 0.1 & 0.1 & 0.6 & 53 & 0.1 & 0.1 & 1.8 & 63 & 0.1 & 0.1 & 2.3 \\
\hline
\end{tabular}

aNorth Italy groups the following regions: Emilia Romagna, Liguria, Lombardy, Trentino Alto Adige, and Veneto.

${ }^{b}$ Central Italy groups the following regions: Abruzzo, Lazio, Marche, Tuscany, and Umbria.

${ }^{c}$ South Italy groups the following regions: Apulia, Calabria, Campania, Sardinia, and Sicily. For each element, numbers in bold with the same superscript indicate significant differences $(\mathrm{p}<0.05)$

oxygen and other chemical elements, unsaturated fatty acid composition, and the presence of antioxidants can affect the oxidation process differently (Frankel 1985). Phenolic compounds have antioxidant capacities in EVOO since they can eliminate peroxyl and alkoxy radicals and chelate transition metal ions present in traces (Visioli et al., 1998). Several elements are known for their antioxidant properties (Perna et al., 2012; Thiruvengadam et al., 2020). Indeed, in the present study (Supplementary Table S8), significant correlations were observed between the antioxidant activity and elements. A positive and significant moderate correlation $(r=0.500-0.768$, $p=0.05$ ) was observed between $\mathrm{Al}, \mathrm{Ca}, \mathrm{Fe}, \mathrm{V}$, and $\mathrm{Zr}$ in EVOOs from Abruzzo, Ba in EVOOs from Apulia, and B, Mn, Se, and V in EVOOs from Sardinia and the DPPH\% data. Conversely, a low and positive correlation $(\mathrm{r}<0.4)$ was recorded between $\mathrm{Ba}$ and $\mathrm{Ni}$ and the antioxidant activity of all samples. Other elements ( $\mathrm{Ag}, \mathrm{Cr}, \mathrm{Cu}$, $\mathrm{Li}, \mathrm{Sb}, \mathrm{Si}$, and $\mathrm{Tl}$ ) might not affect the antioxidant properties as non-significant correlations were observed between them.

Supplementary Tables S5-S7 show the antioxidant activity measured by the DPPH assay (DPPH\%) in the EVOO samples 
TABLE 4 | Summary of significant differences within medians of the 45 selected elements and antioxidant activity (DPPH\%) among all samples from Italian regions by Kruskall-Wallis and pairwise post-hoc tests. A p-value lower than 0.05 was considered statistically significant.

\begin{tabular}{|c|c|c|c|c|c|c|c|c|c|c|}
\hline & Trentino & Liguria & Veneto & Lazio & Tuscany & Umbria & Calabria & Apulia & Sardinia & Sicily \\
\hline Toscany & & DPPH\% & & $\begin{array}{l}\text { Cd, Cs, Dy, Ga, La, Na, Nd, } \\
\text { Pr, Rb, Sb, Tb, Ti, U }\end{array}$ & - & & & & & \\
\hline Umbria & & & & Dy, $\cup$ & & - & & & & \\
\hline Apulia & & & & & $\mathrm{Ti}, \mathrm{Zr}$ & & - & & & \\
\hline Sardinia & & & & $\mathrm{La}, \mathrm{Tb}, \mathrm{U}$ & & & & $\mathrm{Al}$ & - & \\
\hline Sicily & & & & $U$ & Be,DPPH\% & & & DPPH\% & $\mathrm{Be}$ & - \\
\hline Abruzzo & & DPPH\% & $\mathrm{Fe}$ & $\begin{array}{l}\mathrm{Ba}, \mathrm{Ca}, \mathrm{Cd}, \mathrm{Ce}, \mathrm{Dy}, \mathrm{La}, \mathrm{Mg} \\
\mathrm{Nd}, \mathrm{Rb}, \mathrm{Sr}, \mathrm{Tb}\end{array}$ & $\mathrm{Ni}$ & $\mathrm{Fe}, \mathrm{Se}$ & $\mathrm{Fe}$ & $\mathrm{Ce}, \mathrm{La}, \mathrm{Ni}, \mathrm{Zn}, \mathrm{Zr}$ & & $\begin{array}{l}\text { As,Ba, Ca,Ce,Fe,La } \\
\mathrm{Ni}, \mathrm{Zn}, \mathrm{DPPH} \%\end{array}$ \\
\hline Campania & & & & $\mathrm{Ba}, \mathrm{Cd}, \mathrm{La}, \mathrm{Mg}, \mathrm{Na}, \mathrm{Rb}, \mathrm{U}$ & & & $\mathrm{Na}$ & $\mathrm{La}$ & $\mathrm{Na}$ & $\mathrm{Ba}, \mathrm{La}$ \\
\hline Marche & $\mathrm{Na}$ & $\mathrm{Na}$ & $\mathrm{Fe}, \mathrm{Na}$ & $\begin{array}{l}\mathrm{Ba}, \mathrm{Cd}, \mathrm{Ce}, \mathrm{Cs}, \mathrm{La}, \mathrm{Na}, \mathrm{Nd} \\
\mathrm{Mg}, \mathrm{Pb}, \mathrm{Pr}, \mathrm{Rb}, \mathrm{Ti}, \mathrm{U}\end{array}$ & & $\mathrm{Fe}$ & $\mathrm{Cd}, \mathrm{Fe}, \mathrm{Na}$ & $\mathrm{Na}, \mathrm{Rb}, \mathrm{Ti}$ & $\mathrm{Na}$ & $\mathrm{Ba}, \mathrm{Be}, \mathrm{Rb}$ \\
\hline
\end{tabular}

TABLE 5|PLS-DA discrimination between pairs of geographical origin. Figures of merit estimated on the outer loop of the rDCV procedure (expressed as mean \pm standard deviation).

\begin{tabular}{|c|c|c|c|c|c|}
\hline Class1 & Class2 & $\%$ accuracy & $\begin{array}{c}\text { Mean } \% \\
\text { correct classification } \\
\text { rate }\end{array}$ & $\begin{array}{c}\% \text { sensitivity } \\
\text { (Class1) }\end{array}$ & $\begin{array}{c}\% \text { sensitivity } \\
\text { (Class2) }\end{array}$ \\
\hline Lazio & Abruzzo & $76.2 \pm 3.9$ & $77.1 \pm 4.2$ & $73.1 \pm 3.9$ & $81.0 \pm 7.7$ \\
\hline Lazio & Sicily & $79.4 \pm 3.1$ & $79.0 \pm 2.9$ & $81.9 \pm 4.9$ & $76.1 \pm 2.8$ \\
\hline Lazio & Apulia & $68.8 \pm 5.2$ & $68.9 \pm 5.2$ & $64.6 \pm 6.2$ & $73.2 \pm 7.6$ \\
\hline Lazio & Tuscany & $75.2 \pm 1.8$ & $69.2 \pm 2.3$ & $57.8 \pm 4.2$ & $80.6 \pm 2.1$ \\
\hline Lazio & Calabria & $61.7 \pm 5.1$ & $54.4 \pm 5.5$ & $71.9 \pm 5.9$ & $36.9 \pm 8.5$ \\
\hline Abruzzo & Calabria & $81.4 \pm 6.1$ & $81.0 \pm 7.1$ & $82.9 \pm 4.3$ & $79.1 \pm 12.2$ \\
\hline Abruzzo & Sicily & $75.0 \pm 4.3$ & $75.5 \pm 4.4$ & $81.2 \pm 7.6$ & $69.7 \pm 5.9$ \\
\hline Abruzzo & Tuscany & $58.2 \pm 3.4$ & $54.6 \pm 5.6$ & $49.3 \pm 11.6$ & $59.9 \pm 4.0$ \\
\hline Abruzzo & Apulia & $54.3 \pm 6.6$ & $54.2 \pm 6.8$ & $53.6 \pm 9.6$ & $54.8 \pm 7.5$ \\
\hline Sicily & Tuscany & $69.5 \pm 2.7$ & $65.8 \pm 4.1$ & $59.9 \pm 7.6$ & $71.8 \pm 2.8$ \\
\hline Sicily & Apulia & $70.7 \pm 4.3$ & $70.2 \pm 4.2$ & $65.4 \pm 4.9$ & $74.9 \pm 6.5$ \\
\hline Tuscany & Apulia & $64.6 \pm 3.1$ & $55.1 \pm 4.9$ & $72.5 \pm 2.9$ & $37.7 \pm 9.3$ \\
\hline
\end{tabular}

from each region. EVOOs from central and southern Italy showed higher antioxidant activity than oils from northern Italy. In particular, Table 4 shows that EVOOs from Sicily had a significantly lower $\mathrm{DPPH} \%($ median $=18.2 \%)$ than oils from Abruzzo (median $=47 \%)$, Apulia $($ median $=37.6 \%)$, and Tuscany (median $=36.2 \%$ ), while the EVOOs from Liguria had significantly lower DPPH\% (median $=15.7 \%$ ) compared to Tuscany. The highest data of DPPH\% (67.3\%) was found in the oils of Campania. Cioffi et al. (2010) demonstrated that oils from Campania have antioxidant properties, which are very likely due to the presence of high contents of phenolic compounds.

\section{Classification of EVOOs according to geographical origin}

At first, the possibility of discriminating the different EVOOs according to their geographical origin was considered. In particular, due to the unavailability of the information about the origin of all the samples and to the unbalancedness in the distribution of samples per class, when considering the oils of known origin, several two-class models (i.e., comparing two regions at a time) were built and validated. Here it must be further stressed that all the regions for which the available number of certified individuals was too low to be considered representative have not been included in the comparison.

In all cases, PLS-DA analysis was carried out on the matrix made up of the concentrations of the elements presenting at least $70 \%$ of the values above the limit of detection (so to avoid possible artifacts related to data imputation) and including also TEAC and DPPH. Models were built after autoscaling and validated by means of an $\mathrm{rDCV}$ procedure with 50 runs, 10 cancelation groups in the outer loop (the one mimicking the external test set) and 5 in the inner loop (the one used for model selection, i.e., definition of the optimal number of latent variables). The results obtained are summarized in Table $\mathbf{5}$, where the accuracy, the mean correct classification rate, and the sensitivities for the two compared classes are reported. Since two-class discriminant models were calculated, due to symmetry the sensitivity of a class (true positive rate) is the specificity (true negative rate) of the other category; this is why sensitivities only have been reported. Moreover, since the number of samples per class was, in some cases, highly unbalanced (Table 1), we have decided to report both classification accuracy (percentage of correctly classified 


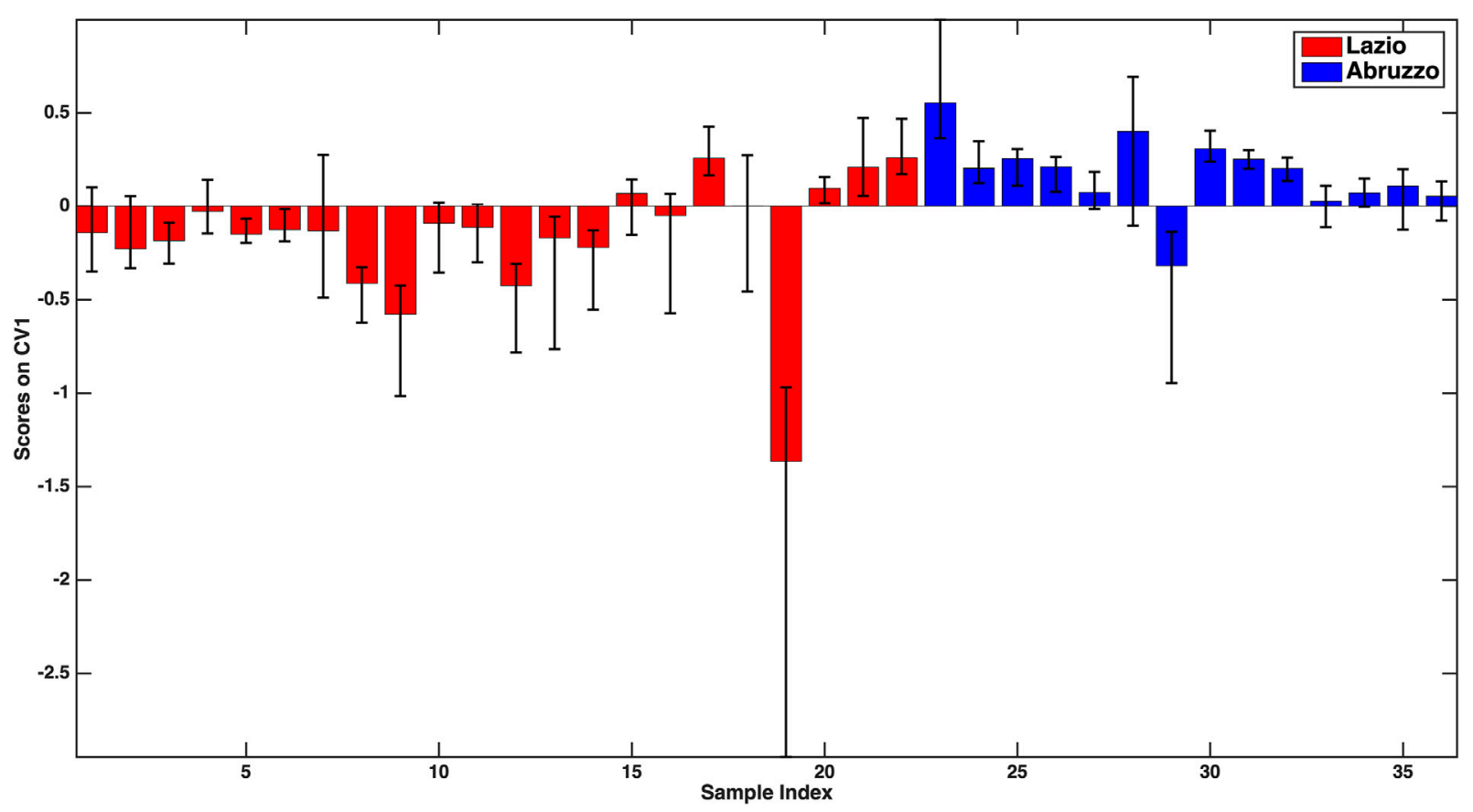

FIGURE 1 | -PLS-DA model for the discrimination between Lazio and Abruzzo samples: mean scores of the rDCV outer loop samples along the only canonical variate of the model together with their $95 \%$ confidence intervals. Legend: red bars-Lazio; blue bars-Abruzzo.

samples irrespectively of the category over the total number of samples) and the mean correct classification rate, which is the average of the specificities of the two classes.

As anticipated in the materials and methods section, the use of repeated double cross-validation allows obtaining not only a point estimate of the figures of merit on the validation (outer loop) samples but also their confidence intervals, so as to be able to evaluate the consistency of the results.

By looking at Table 5, it is evident how the different models result in different reliabilities, with some presenting rather low classification performances. On the other hand, there are some models which result in an overall accuracy higher than $75 \%$, with a comparable mean correct classification rate (suggesting that the classification performances are not affected by the numerosity of the samples; Table 1). Additionally, the standard deviation of the figures of merit for these models is relatively low (corresponding roughly to one more sample being correctly or wrongly classified with respect to the reported averages), confirming the consistency of the obtained classification. Based on these considerations, only the best models will be discussed in detail in the remainder of this section, namely, Lazio vs. Abruzzo, Lazio vs. Sicily, Abruzzo vs. Calabria and Abruzzo vs. Sicily.

The first model to be examined is the one discriminating Lazio samples from the oils from Abruzzo, for which an overall $76.2 \pm 3.9 \%$ classification accuracy on the outer loop samples was registered. By looking at the individual sensitivities together with their confidence intervals $(73.1 \pm 3.9 \%$ for Lazio and $81.0 \pm 7.7 \%$ for Abruzzo), it can be stated that the two categories are predicted comparably well. These results can also be graphically appreciated in Figure 1, where the mean scores of the outer loop samples along the only canonical variate of the model together with their 95\% confidence intervals are displayed. It is evident from Figure 1 how almost all the Abruzzo samples have positive scores, while the large majority of Lazio samples are characterized by negative coordinates on the component, indicating a good separation between the categories.

For the sake of interpretation, another advantage of the rDCV procedure is that confidence intervals can also be calculated for model parameters, so as to be able to identify which are the variables that contribute significantly to the discrimination (e.g., by inspecting the values of the associated regression coefficients or of the VIP scores). Moreover, investigating the sign of the regression coefficients also allows postulating whether the associated predictor is more or less concentrated in a category with respect to the other. In particular, the variables found to significantly contribute to the discriminant model were $\mathrm{V}, \mathrm{Fe}, \mathrm{Zn}$, $\mathrm{Rb}$, antioxidant capacity (all higher in Lazio samples), and $\mathrm{Ni}$ and antioxidant activity in the DPPH assay (higher in the oils from Abruzzo).

As far as the Lazio vs. Sicily model is concerned, a slightly higher accuracy was obtained $(79.4 \pm 3.1 \%)$, the individual sensitivities being $81.9 \pm 4.9 \%$ for Lazio and $76.1 \pm 2.8 \%$ for Sicily. Analogously to that described above, the discrimination between the two classes can also be visually appreciated in Figure 2, where the mean scores of the outer loop samples along the only canonical variate of the model together with their 95\% confidence intervals are displayed.

In this case, based on the values of the PLS-DA regression coefficients, all the variables found to significantly contribute 


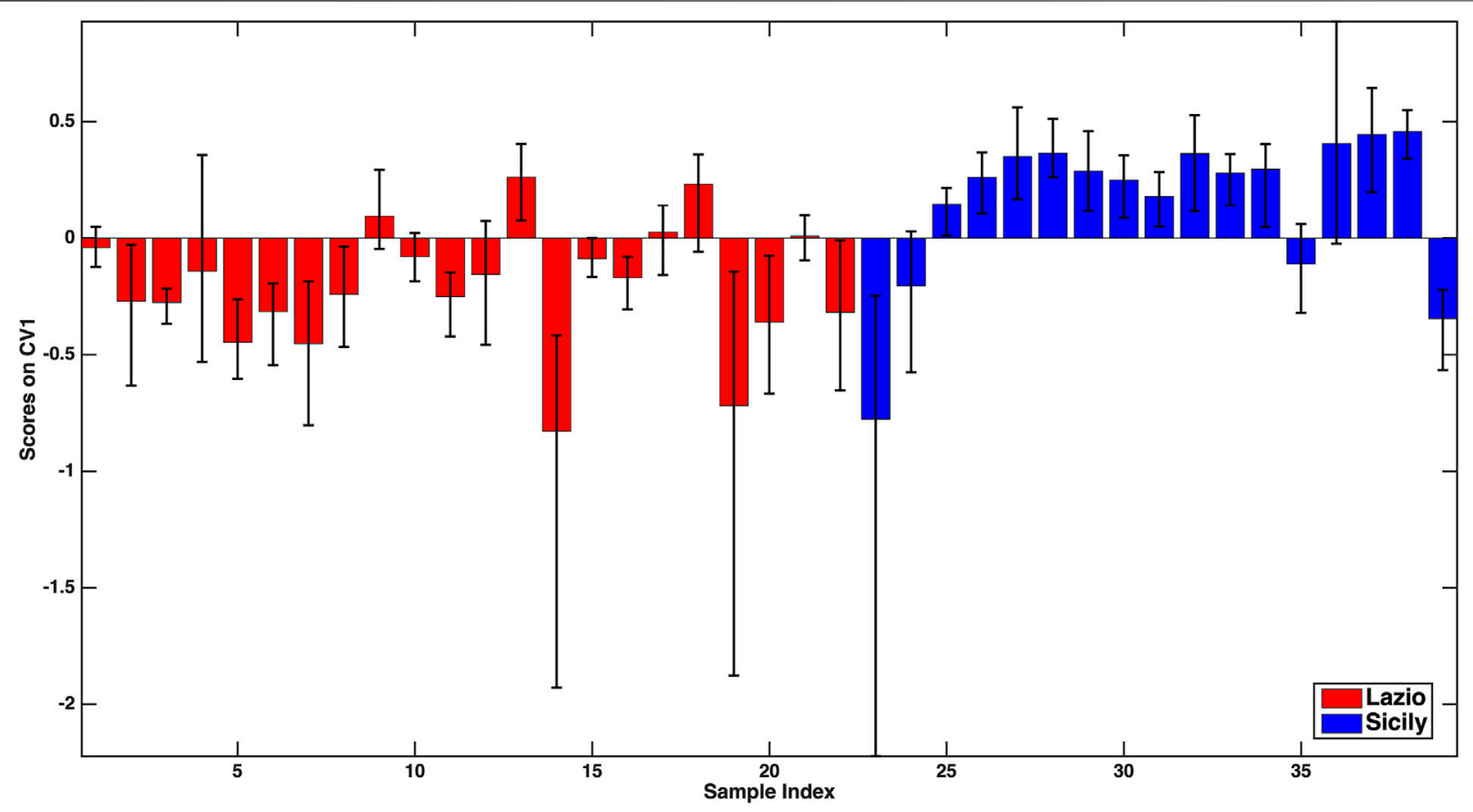

FIGURE 2 |-PLS-DA model for the discrimination between Lazio and Sicily samples: mean scores of the rDCV outer loop samples along the only canonical variate of the model together with their 95\% confidence intervals. Legend: red bars-Lazio; blue bars-Sicily.

to the discriminant model $(\mathrm{Na}, \mathrm{Mg}, \mathrm{P}, \mathrm{Ti}, \mathrm{Rb}$, antioxidant activity in the DPPH assay) should be, on average, higher in the oils from Lazio. When considering the model discriminating Abruzzo oils from the Calabrian ones, an overall $81.4 \pm 6.1 \%$ accuracy on the outer loop samples was obtained, the mean correct classification rate $(81.0 \pm 7.1 \%)$ and the individual sensitivities for the two categories $(82.9 \pm 4.35 \%$ for Abruzzo and $79.1 \pm 12.2 \%$ for Calabria) being almost equal. In particular, the higher standard deviation of the sensitivity for Calabria is due to the very limited number of samples in that class. When looking at the significant predictors, only five variables ( $\mathrm{P}, \mathrm{V}, \mathrm{Fe}, \mathrm{Zn}$, and antioxidant activity) were identified, and the coefficients indicate that they all should be, on average, higher for the Abruzzo samples.

Lastly, the Abruzzo vs. Sicily model resulted in an accuracy of $75.0 \pm 4.3 \%$, the sensitivities being $81.2 \pm 7.6 \%$ for Abruzzo and $69.7 \pm 5.9 \%$ for Sicily. Inspection of the model parameters led to identifying as significant the contribution of $\mathrm{Na}, \mathrm{Ni}$, and antioxidant activity (in the DPPH assay with higher data in the oils from Abruzzo) and of $\mathrm{V}$ and $\mathrm{Fe}$, more concentrated in the samples from Sicily.

Classification of EVOOs according to cultivar and to whether it was organically produced.

In a second stage of the study, the possibility of discriminating oil samples according to their cultivar was explored. In this case, given the available information about the samples and the fact that only a relatively small fraction of the analyzed oils was monovarietal, the investigation was restricted to the comparison of Coratina (21 samples) and Frantoio (12 samples) (Table 1). The PLS-DA classification approach was validated through an rDCV strategy as described in the previous section and resulted in an overall accuracy of $68.9 \pm 6.2 \%$, and $80.7 \pm 8.8 \%$ and $61.9 \pm$ $7.6 \%$ sensitivities for Frantoio and Coratina, respectively, corresponding to a mean correct classification rate of $71.3 \pm$ $6.2 \%$. Investigation of the model parameters suggested that five variables only, namely, $\mathrm{P}, \mathrm{Ti}, \mathrm{Zn}$ (higher in Coratina), Fe, and $\mathrm{Ni}$ (more concentrated in Frantoio), significantly contributed to the discriminant model.

Lastly, the possibility of discriminating whether the oil was organically produced or not was also attempted, but the classification model resulted in a very poor accuracy (close to $50 \%$ ) suggesting that, at least for the investigated samples, organic cultivation has little impact on the elemental composition with respect to non-organic production.

\section{CONCLUSION}

This study showed that the $\mathrm{As}, \mathrm{Cu}, \mathrm{Fe}$, and $\mathrm{Pb}$ levels in the analyzed samples were far below the MRLs, which certifies the high quality of Italian EVOO.

The element concentrations allow to distinguish well some geographical origins of the EVOO samples and also, although slightly less well, the two cultivars Coratina and Frantoio. On the other hand, given the high heterogeneity of the data set, it is not possible to distinguish organic oils from non-organic ones. This is 
probably due to the fact that within the two classes the variability related to geographical origin and cultivar is added.

This study can be used to create datasets for element levels in EVOOs for each production region to support geographic origin authentication. In the future, other information will have to be considered together with the elemental profile of EVOO such as climatic factors and bioavailable fraction of the total content of elements to further corroborate the use of the elements as a marker of provenance.

\section{DATA AVAILABILITY STATEMENT}

The original contributions presented in the study are included in the article/Supplementary Material; further inquiries can be directed to the corresponding author.

\section{AUTHOR CONTRIBUTIONS}

ML-A: conceptualization, investigation, methodology, validation, formal analysis, visualization, data curation, writing-original draft preparation, writing-reviewing and editing and supervision. FM: methodology, validation, formal analysis, writing-original draft preparation and

\section{REFERENCES}

Aceto, M., Calà, E., Musso, D., Regalli, N., and Oddone, M. (2019). A preliminary study on the authentication and traceability of extra virgin olive oil made from Taggiasca olives by means of trace and ultra-trace elements distribution. Food Chemistry 298, 125047. doi:10.1016/j.foodchem.2019.125047

Astolfi, M. L., Conti, M. E., Marconi, E., Massimi, L., and Canepari, S. (2020a). Effectiveness of Different Sample Treatments for the Elemental Characterization of Bees and Beehive Products. Molecules 25, 4263. doi:10.3390/molecules25184263

Astolfi, M. L., Marconi, E., Protano, C., and Canepari, S. (2020b). Comparative elemental analysis of dairy milk and plant-based milk alternatives. Food Control 116, 107327. doi:10.1016/j.foodcont.2020.107327

Astolfi, M. L., Marconi, E., Vitiello, G., and Massimi, L. (2021b). An optimized method for sample preparation and elemental analysis of extra-virgin olive oil by inductively coupled plasma mass spectrometry. Food Chemistry 360, 130027. doi:10.1016/j.foodchem.2021.130027

Astolfi, M. L., Marotta, D., Cammalleri, V., Marconi, E., Antonucci, A., Avino, P., et al. (2021a). Determination of 40 Elements in Powdered Infant Formulas and Related Risk Assessment. Ijerph 18, 5073. doi:10.3390/ijerph18105073

Astolfi, M. L., Protano, C., Marconi, E., Massimi, L., Brunori, M., Piamonti, D., et al. (2020c). A new rapid treatment of human hair for elemental determination by inductively coupled mass spectrometry. Anal. Methods 12, 1906-1918. doi:10.1039/c9ay01871a

Bajoub, A., Bendini, A., Fernández-Gutiérrez, A., and Carrasco-Pancorbo, A. (2018). Olive oil authentication: A comparative analysis of regulatory frameworks with especial emphasis on quality and authenticity indices, and recent analytical techniques developed for their assessment. A review. Crit. Rev. Food Sci. Nutr. 58, 832-857. doi:10.1080/10408398.2016.1225666

Bakircioglu, D., Kurtulus, Y. B., and Yurtsever, S. (2013). Comparison of extraction induced by emulsion breaking, ultrasonic extraction and wet digestion procedures for determination of metals in edible oil samples in Turkey using ICP-OES. Food Chemistry 138, 770-775. doi:10.1016/ j.foodchem.2012.10.089 writing-reviewing and editing. MA-F: investigation. LM: formal analysis. ALC: resources. CMM: resources. SC: resources and supervision.

\section{FUNDING}

This work was partially supported by the "Agroalimentare e Ricerca” (AGER) program, project AGER2-Rif.20160169, "Valorization of Italian Olive products through INnovative analytical tools-VIOLIN".

\section{ACKNOWLEDGMENTS}

We thank Dr. Elisabetta Marconi, and Dr. Giulia Vitiello for their excellent support in the treatment and classification of the samples.

\section{SUPPLEMENTARY MATERIAL}

The Supplementary Material for this article can be found online at: https://www.frontiersin.org/articles/10.3389/fchem.2021.769620/ full\#supplementary-material

Barker, M., and Rayens, W. (2003). Partial least squares for discrimination. J. Chemometrics 17, 166-173. doi:10.1002/cem.785

Beltrán, M., Sánchez-Astudillo, M., Aparicio, R., and García-González, D. L. (2015). Geographical traceability of virgin olive oils from south-western Spain by their multi-elemental composition. Food Chemistry 169, 350-357. doi:10.1016/j.foodchem.2014.07.104

Bendini, A., Cerretani, L., Carrasco-Pancorbo, A., Gómez-Caravaca, A., SeguraCarretero, A., Fernández-Gutiérrez, A., et al. (2007). Phenolic Molecules in Virgin Olive Oils: a Survey of Their Sensory Properties, Health Effects, Antioxidant Activity and Analytical Methods. An Overview of the Last Decade Alessandra. Molecules 12 (8), 1679-1719. doi:10.3390/12081679

Benincasa, C., Lewis, J., Perri, E., Sindona, G., and Tagarelli, A. (2007). Determination of trace element in Italian virgin olive oils and their characterization according to geographical origin by statistical analysis. Analytica Chim. Acta 585, 366-370. doi:10.1016/j.aca.2006.12.040

Cabrera-Vique, C., Bouzas, P. R., and Oliveras-López, M. J. (2012). Determination of trace elements in extra virgin olive oils: A pilot study on the geographical characterisation. Food Chemistry 134 (1), 434-439. doi:10.1016/ j.foodchem.2012.02.088

Camin, F., Larcher, R., Perini, M., Bontempo, L., Bertoldi, D., Gagliano, G., et al. (2010). Characterisation of authentic Italian extra-virgin olive oils by stable isotope ratios of $\mathrm{C}, \mathrm{O}$ and $\mathrm{H}$ and mineral composition. Food Chemistry 118, 901-909. doi:10.1016/j.foodchem.2008.04.059

Capriotti, A. L., Cavaliere, C., Crescenzi, C., Foglia, P., Nescatelli, R., Samperi, R., et al. (2014). Comparison of extraction methods for the identification and quantification of polyphenols in virgin olive oil by ultra-HPLC-QToF mass spectrometry. Food Chemistry 158, 392-400. doi:10.1016/ j.foodchem.2014.02.130

Carbone, A., Cacchiarelli, L., and Sabbatini, V. (2018). Exploring quality and its value in the Italian olive oil market: a panel data analysis. Agric. Econ. 6, 6. doi:10.1186/s40100-018-0102-8

Chatzistathis, T., Therios, I., and Alifragis, D. (2009). Differential uptake, distribution within tissues, and use efficiency of manganese, iron, and zinc by olive cultivars Kothreiki and Koroneiki. horts 44, 1994-1999. doi:10.21273/ HORTSCI.44.7.1994 
Choe, E., and Min, D. B. (2006). Mechanisms and factors for edible oil oxidation. Comp. Rev. Food Sci. Food Saf. 5, 169-186. doi:10.1111/j.15414337.2006.00009.x

Christodouleas, D. C., Fotakis, C., Nikokavoura, A., Papadopoulos, K., and Calokerinos, A. C. (2015). Modified DPPH and ABTS assays to assess the antioxidant profile of untreated oils. Food Anal. Methods 8 (5), 1294-1302. doi:10.1007/s12161-014-0005-6

Cioffi, G., Pesca, M. S., De Caprariis, P., Braca, A., Severino, L., and De Tommasi, N. (2010). Phenolic compounds in olive oil and olive pomace from Cilento (Campania, Italy) and their antioxidant activity. Food Chemistry 121 (1), 105-111. doi:10.1016/j.foodchem.2009.12.013

Codex Stan 33-1981 (2021). Standard for Olive Oils and Olive Pomace Oils. Adopted in 1981Revision: 1989, 2003, 2015. Amendment: 2009, 2013. URL: http://www.fao. org/input/download/standards/88/CXS_033e_2015.pdf (accessed on April, 2021).

Cordella, C., Moussa, I., Martel, A.-C., Sbirrazzuoli, N., and Lizzani-Cuvelier, L. (2002). Recent developments in food characterization and adulteration detection: Technique-oriented perspectives. J. Agric. Food Chem. 50, 1751-1764. doi:10.1021/jf011096z

Damak, F., Asano, M., Baba, K., Suda, A., Araoka, D., Wali, A., et al. (2019). Interregional traceability of Tunisian olive oils to the provenance soil by multielemental fingerprinting and chemometrics. Food Chemistry 283, 656-664. doi:10.1016/j.foodchem.2019.01.082

Dugo, L., Russo, M., Cacciola, F., Mandolfino, F., Salafia, F., Vilmercati, A., et al. (2020). Determination of the phenol and tocopherol content in italian highquality extra-virgin olive oils by using LC-MS and multivariate data analysis. Food Anal. Methods 13, 1027-1041. doi:10.1007/s12161-020-01721-7

European Union (EU) (20122012). The Commission Regulation No. 1151/2012 of 21 November 2012 on quality schemes for agricultural products and foodstuffs OJ L 343/1, 14.12. Available online: https://eur-lex.europa.eu/legal-content/EN/ TXT/PDF/?uri=CELEX:32012R1151\&from=EN (accessed on August, 2021).

Eurostat (2019). Olive trees - Area by age and density classes (area in ha). Available online: http://appsso.eurostat.ec.europa.eu/nui/show.do?dataset=orch_ olives3\&lang=en (accessed on August, 2021).

Farmaki, E. G., Thomaidis, N. S., Minioti, K. S., Ioannou, E., Georgiou, C. A., and Efstathiou, C. E. (2012). Geographical characterization of Greek olive oils using rare earth elements content and supervised chemometric techniques. Anal. Lett. 45, 920-932. doi:10.1080/00032719.2012.655656

Filzmoser, P., Hron, K., and Reimann, C. (2009). Principal Component Analysis for Compositional Data With Outliers. Environmetrics: The Official Journal of the International Environmetrics Society 20 (6), 621-632. doi:10.1002/env.966

Frankel, E. N. (1985). "Chemistry of autoxidation: mechanism, products and flavor significance," in Flavor Chemistry of Fats and Oils. Editors D. B. Min and T. H. Smouse (Champaign, IL (USA): AOCS Press), 1-37.

Frezzini, M. A., Castellani, F., De Francesco, N., Ristorini, M., and Canepari, S. (2019). Application of DPPH assay for assessment of particulate matter reducing properties. Atmosphere 10 (12), 816. doi:10.3390/atmos10120816

Giaccio, M., and Vicentini, A. (2008). Determination of the geographical origin of wines by means of the mineral content and the stable isotope ratios: A review. J. Comm. Sci. Technol. Qual. 47 (I-IV), 267-284.

Giacomo, D., Pera Lara, L., Daniele, G., Francesco, S., and Turco Vincenzo, L. (2004). Influence of the olive variety and the zone of provenience on selenium content determined by cathodic stripping potentiometry (CSP) in virgin olive oils. Food Chemistry 88, 135-140. doi:10.1016/j.foodchem.2003.12.036

Gonzalez-Fernandez, I., Iglesias-Otero, M. A., Esteki, M., Moldes, O. A., Mejuto, J. C., and Simal-Gandara, J. (2019). A critical review on the use of artificial neural networks in olive oil production, characterization and authentication. Crit. Rev. Food Sci. Nutr. 59 (12), 1913-1926. doi:10.1080/10408398.2018.1433628

Gumus, Z. P., Celenk, V. U., Tekin, S., Yurdakul, O., and Ertas, H. (2017). Determination of trace elements and stable carbon isotope ratios in virgin olive oils from Western Turkey to authenticate geographical origin with a chemometric approach. Eur. Food Res. Technol. 243, 1719-1727. doi:10.1007/ s00217-017-2876-4

Hannachi, H., and Elfalleh, W. (2020). Enrichment of olive oil with polyphenols from oleaster leaves using central composite design for the experimental measurements. Anal. Lett. 54, 590-607. doi:10.1080/00032719.2020.1774599

International Olive Council (IOC) (2018a). IOC data for the 2017/18 crop year show a year-on-year increase in the production of olive oil. Available online: http://www.internationaloliveoil.org/news/view/698-year-2018-news/1049- ioc-data-for-the-2017-18-crop-year-show-a-year-on-year-increase-in-theproduction-of-olive-oil (accessed on August, 2021).

International Olive Council (IOC) (2019). Trade standard applying to olive oils and olive-pomace oils. COI/T.15/NC No. 3/Rev. 15. Available online: https://www. internationaloliveoil.org/wp-content/uploads/2020/07/Trade-standard-T15NC3-Rev15-EN.pdf (accessed on April, 2021).

International Olive Council (IOC) (2018b). World Olive Oil Figures. Available online: http://www.internationaloliveoil.org/estaticos/view/131-world-oliveoilfigures (accessed on August, 2021).

Kabata-Pendias, A. (2010). Trace elements in soils and plants. 4th ed. Boca Raton: CRC Press. doi:10.1201/b10158

Kedare, S. B., and Singh, R. P. (2011). Genesis and development of DPPH method of antioxidant assay. J. Food Sci. Technol. 48 (4), 412-422. doi:10.1007/s13197011-0251-1

Kelly, S., Heaton, K., and Hoogewerff, J. (2005). Tracing the geographical origin of food: The application of multi-element and multi-isotope analysis. Trends Food Sci. Tech. 16, 555-567. doi:10.1016/j.tifs.2005.08.008

Lepri, F. G., Chaves, E. S., Vieira, M. A., Ribeiro, A. S., Curtius, A. J., DeOliveira, L. C. C., et al. (2011). Determination of Trace Elements in Vegetable Oils and Biodiesel by Atomic Spectrometric Techniques-A Review. Appl. Spectrosc. Rev. 46, 175-206. doi:10.1080/05704928.2010.529628

Llorent-Martínez, E. J., Fernández-de Córdova, M. L., Ortega-Barrales, P., and RuizMedina, A. (2014). Quantitation of Metals During the Extraction of Virgin Olive Oil From Olives Using ICP-MS After Microwave-Assisted Acid Digestion. J. Am. Oil Chem. Soc. 91, 1823-1830. doi:10.1007/s11746-014-2511-5

Llorent-Martínez, E. J., Ortega-Barrales, P., Fernández-de Córdova, M. L., and Ruiz-Medina, A. (2011). Analysis of the legislated metals in different categories of olive and olive-pomace oils. Food Control 22, 221-225. doi:10.1016/ j.foodcont.2010.07.002

Luka, M. F., and Akun, E. (2019). Investigation of trace metals in different varieties of olive oils from northern Cyprus and their variation in accumulation using ICP-MS and multivariate techniques. Environ. Earth Sci. 78, 578. doi:10.1007/ s12665-019-8581-9

Mendil, D., Uluözlü, Ö. D., Tüzen, M., and Soylak, M. (2009). Investigation of the levels of some element in edible oil samples produced in Turkey by atomic absorption spectrometry. J. Hazard. Mater. 165, 724-728. doi:10.1016/ j.jhazmat.2008.10.046

Pérez, N. F., Ferré, J., and Boqué, R. (2009). Calculation of the reliability of classification in discriminant partial least-squares binary classification. Chemometrics Intell. Lab. Syst. 95, 122-128. doi:10.1016/ j.chemolab.2008.09.005

Pérez-Jiménez, J., Arranz, S., Tabernero, M., Díaz- Rubio, M. E., Serrano, J., Goñi, I., et al. (2008). Updated methodology to determine antioxidant capacity in plant foods, oils and beverages: Extraction, measurement and expression of results. Food Res. Int. 41 (3), 274-285. doi:10.1016/ j.foodres.2007.12.004

Perna, A., Simonetti, A., Intaglietta, I., Sofo, A., and Gambacorta, E. (2012). Metal content of southern Italy honey of different botanical origins and its correlation with polyphenol content and antioxidant activity. Int. J. Food Sci. Technol. 47, 1909-1917. doi:10.1111/j.1365-2621.2012.03050.x

Pohl, W. L. (2011). Economic geology: Principles and practice. New Jersey: WileyBlackwell. 978-1-444-33663-4. doi:10.1002/9781444394870

Pošćić, F., Furdek Turk, M., Bačić, N., Mikac, N., Bertoldi, D., Camin, F., et al. (2019). Removal of pomace residues is critical in quantification of element concentrations in extra virgin olive oil. J. Food Compost. Anal. 77, 39-46. doi:10.1016/j.jfca.2019.01.002

Russo, G., Beritognolo, I., Bufacchi, M., Stanzione, V., Pisanelli, A., Ciolfi, M., et al. (2020). Advances in biocultural geography of olive tree (Olea europaea L.) landscapes by merging biological and historical assays. Sci. Rep. 10, 7673. doi:10.1038/s41598-020-64063-8

Šarolić, M., Gugić, M., Tuberoso, C., Jerković, I., Šuste, M., Marijanović, Z., et al. (2014). Volatile Profile, Phytochemicals and Antioxidant Activity of Virgin Olive Oils from Croatian Autochthonous Varieties Mašnjača and Krvavica in Comparison with Italian Variety Leccino. Molecules 19 (1), 881-895. doi:10.3390/molecules19010881

Shah, N. S., and Soylak, M. (2021). Advanced methodologies for trace elements in edible oil samples: a review. Crit. Rev. Anal. Chemistry 15, 1-20. doi:10.1080/ 10408347.2021.1895710 
Ståhle, L., and Wold, S. (1987). Partial least squares analysis with cross-validation for the two-class problem: A Monte Carlo study. J. Chemometrics 1, 185-196. doi:10.1002/cem.1180010306

Tchounwou, P. B., Yedjou, C. G., Patlolla, A. K., and Sutton, D. J. (2012). Heavy Metal Toxicity and the Environment. Exp. Suppl. 101, 133-164. doi:10.1007/ 978-3-7643-8340-4_6

Thiruvengadam, M., Ghimire, B. K., Kim, S.-H., Yu, C. Y., Oh, D.-H., Chelliah, R., et al. (2020). Assessment of mineral and phenolic profiles and their association with the antioxidant, cytotoxic effect, and antimicrobial potential of Lycium chinense Miller. Plants 9 (8), 1023. doi:10.3390/plants9081023

Trindade, A. S., Dantas, A. F., Lima, D. C., Ferreira, S .L., and Teixeira, L. S. (2015). Multivariate Optimization of Ultrasound-Assisted Extraction for Determination of $\mathrm{Cu}, \mathrm{Fe}, \mathrm{Ni}$, and $\mathrm{Zn}$ in Vegetable Oils by High-Resolution Continuum Source Atomic Absorption Spectrometry. Food Chem. 15 (185), 145-150. doi:10.1016/j.foodchem.2015.03.118

Visioli, F., Bellomo, G., and Galli, C. (1998). Free radical-scavenging properties of olive oil polyphenols. Biochem. Biophysical Res. Commun. 247 (1), 60-64. doi:10.1006/bbrc.1998.8735

Wold, S., Martens, H., and Wold, H. (1983). "The multivariate calibration problem in chemistry solved by the PLS method," in Matrix Pencils. Lecture Notes in Mathematics. Editors B. Kågström and A. Ruhe. 1st ed. (Germany: Springer, Berlin/Heidelberg), 973, 286-293. doi:10.1007/BFb0062108

Yaşar, S. B., Baran, E. K., and Alkan, M. (2012). "Metal determinations in olive oil, Olive oil - Constituents, quality, health properties and bioconversions," in InTech. Editor Dr. Dimitrios Boskou. Available online: http://www.intechopen.com/books/oliveoil-constituents-quality-healthproperties-and-bioconversions/metal-determinationsin-olive-oil (accessed on July, 2021).

Zaroual, H., Chénè, C., El Hadrami, E. M., and Karoui, R. (2021). Application of new emerging techniques in combination with classical methods for the determination of the quality and authenticity of olive oil: a review. Crit. Rev. Food Sci. Nutr. 1, 1-24. doi:10.1080/ 10408398.2021.1876624

Zeiner, M., Juranovic-Cindric, I., and Škevin, D. (2010). Characterization of extra virgin olive oils derived from the Croatian cultivar Oblica. Eur. J. Lipid Sci. Technol. 112, 1248-1252. doi:10.1002/ejlt.201000006

Zeiner, M., Steffan, I., and Cindric, I. J. (2005). Determination of trace elements in olive oil by ICP-AES and ETA-AAS: A pilot study on the geographical characterization. Microchemical J. 81, 171-176. doi:10.1016/ j.microc.2004.12.002

Conflict of Interest: The authors declare that the research was conducted in the absence of any commercial or financial relationships that could be construed as a potential conflict of interest.

Publisher's Note: All claims expressed in this article are solely those of the authors and do not necessarily represent those of their affiliated organizations, or those of the publisher, the editors, and the reviewers. Any product that may be evaluated in this article, or claim that may be made by its manufacturer, is not guaranteed or endorsed by the publisher.

Copyright (C) 2021 Astolfi, Marini, Frezzini, Massimi, Capriotti, Montone and Canepari. This is an open-access article distributed under the terms of the Creative Commons Attribution License (CC BY). The use, distribution or reproduction in other forums is permitted, provided the original author(s) and the copyright owner(s) are credited and that the original publication in this journal is cited, in accordance with accepted academic practice. No use, distribution or reproduction is permitted which does not comply with these terms. 